\title{
Research on the Reform of Classroom Teaching in Colleges in the Age of "Internet +"__ A Case Study of "Public Service Management"
}

\author{
Yanli Fu ${ }^{1, a}$ \\ Jilin Engineering Normal University, Changchun, Jilin, 130000 \\ a email: 22515609@qq.com
}

Keywords: public service management; classroom teaching; reform education

\begin{abstract}
At present, the teaching of public service management majors faces two major dilemmas: one is the disconnection between public management teaching theory and practice, and the other is the lack of initiative and innovation of students. The applicability of research teaching applied to the classroom teaching of public management courses is reflected in: it is beneficial to enhance students' interest in learning and motivation; it is conducive to building a platform for students to integrate knowledge and cooperation; it is conducive to cultivating students' innovative and entrepreneurial ability, and comprehensive quality. The research teaching reform of the public service management major should focus on the reform of teaching resources, the reform of teaching content, the reform of teaching organization, the reform of teaching methods and the reform of student academic evaluation.
\end{abstract}

\section{Introduction}

With the acceleration of knowledge update, the increasingly fierce social competition and institutional changes in the public sector, it has brought severe challenges to the cultivation of public service management talents in universities. In particular, the gradual deepening of the reform of public institutions in China has undoubtedly put forward new and higher requirements for the teaching reform of public service management courses. This objectively requires teachers in China's higher education and teaching in public service management courses to pay attention to these changes, and then adapt and meet these changes. In addition, because the traditional teacher-centered teaching model and / cramming 0 teaching methods still occupy a dominant position, students' initiative, participation and creativity are constrained. To this end, we need to actively explore new ways of teaching public utilities management courses in Colleges, strive to improve students' interest in learning and teaching effects, continuously reform and innovate, and cultivate public enterprise management talents that can meet the requirements of the times and have comprehensive capabilities.

\section{The Necessity of Constructing a Practical Teaching System for Public Service Management}

Management disciplines are applied and practical disciplines. They not only require students to master basic theories, basic methods and basic skills, but also emphasize that students have excellent practical skills. This requires more emphasis on practical teaching links in the teaching process. The design forms a relatively complete practical teaching system. The Ministry of Education has listed the public service management profession as a major under the first-level discipline of public administration. It has the knowledge of modern management theory, techniques and methods, and the ability to apply this knowledge. It can be used in culture, education, sports, health, and environmental protection. High-level specialized personnel engaged in management work in public institutions such as social insurance and community management. In 1998, the Ministry of Education adjusted the undergraduate enrollment catalogue of ordinary Colleges and added a major in public service management. In recent years, the profession has developed rapidly, and more than 300 Colleges across the country have set up this major. All Colleges have made 
in-depth research and exploration on the training mode, training specifications and training programs of the professional talents, which makes the professional teaching plan perfect day by day, and the content of classroom teaching is gradually becoming scientific and rational, and the construction of the curriculum system is also beginning to see. Results. However, due to the limitations of many conditions, the practical teaching links of public utilities management majors in universities are generally weak. There are many problems in the practice teaching process, such as the lack of basic teaching documents, the narrowness of practical content setting, and the lag of the construction of practice bases. The perfect practice teaching system of the public service management profession has not yet been formed, which has become the "bottleneck" for cultivating high-quality management talents with strong practical ability. Therefore, according to the law of practical teaching, constructing a perfect practice teaching system for public service management, and improving students' practical ability is the key to promoting the healthy and sustainable development of the profession.

\section{Difficulties and Challenges in the Teaching of Public Service Management Majors}

Since the emergence of the public administration discipline as an independent discipline in China in the 1990s, it has been drawing on the political, economic, sociological, and psychology disciplines to enrich itself, but it also faces the development of science and professionalism. Eternality problem. From the teaching content, there are knowledge breaks in some chapters of the textbook, which is reflected in the knowledge management system of public management theory and between theoretical knowledge and practical public management practice. From the perspective of student psychology, cognition and emotion are the two elements of human psychological development. The lack of cognitive (thinking process) participation in "intuition" or "inspiration" often leads to fantasy and blindness, but lacks emotion (experience process The "rational understanding" of support is difficult to be internalized by students. The limitations of students' own experiences and experiences determine the difficulty of internalization of curriculum knowledge. Course teaching urgently needs to guide students to generate positive emotions through the personal experience of inquiry learning, and gradually form a psychological tendency to explore and strive for knowledge; it is necessary to guide students to strengthen knowledge understanding, application and innovation through practical operation, and acquire public management methods and skills.

Long-term exam-oriented education and public management teaching content is outdated, teaching methods are single, teaching resources are insufficient, and extracurricular innovation activities are not enough. As a result, students generally adopt accepted learning, which limits the development of students' rational inquiry ability. Judging from the quality of the thesis of the public service management profession of the author in recent years, although there are such different problems, some common problems are worth pondering. First, many of the papers of the students have problems such as large selection, lack of reality, and innovation. After studying for four years, I can't find a suitable topic. What is the reason? The fundamental reason is that there is no in-depth practice, no understanding of the current public management practices in China, no problems found, and no scientific problems. Second, it is not good at analyzing and solving problems from the perspective of public management, and it does not reflect good theoretical accomplishments and professional standards. After a long time why professional learning ability problems in the aspects of theoretical knowledge and analysis still has to solve larger lacking? The main reason is that in most of the courses, students did not experience the personal experience of inquiry learning, and the subject theory and knowledge were not truly internalized. The construction of the internship base is a necessary prerequisite for ensuring the quality of the internship. Whether the construction of the internship base meets the professional needs and whether it is appropriate to play an important role in cultivating students' innovative spirit and improving the overall quality of students. However, due to the fact that the reform of the administrative system in China is obviously lagging behind the reform of the economic system, the transformation of government functions has not been in place, and the reform of existing institutions has not yet been completed. The social affairs management functions that the government has taken over in the past have not been completely handed over to 
the public administration, public utilities. The management organization's model can only be the future target model. Such a social environment makes the internship more difficult. From the effect of graduation internships in some schools, it is not satisfactory. At present, most schools adopt a decentralized internship method, students contact their own work units, and most of the students' internships are concentrated in various types of enterprises, and the internships are also varied, from production and sales to human resource management and financial management. , all-inclusive, the content of the internship is far from the profession. Such an internship is far from being able to achieve the internship goal.

\section{The Path and Main Content of Research-based Teaching Reform in Public Service Management Majors}

The reform of public administration majors along the line "dividing the curriculum knowledge teaching unit with the requirements of public management practice and discipline logic The evaluation and incentive guidance is carried out. The main implementation steps: First, the student's academic level and personality characteristics of the positioning diagnosis. It is mainly to diagnose the students' knowledge base and their own interests, personality characteristics and ability advantages, and lay the foundation for group members and phased project tasks. The second is the curriculum knowledge structure setting and diagnosis. It is mainly to sort out the course knowledge, set up a staged knowledge structure, and diagnose its systemic, internal logic, progressive teaching objectives, and academic frontier. Discussed and agreed by the teaching team. The third is the task setting and discussion of the phased project. The main purpose is to design a project project that not only reflects the teaching objectives and requirements, but also reflects the current hotspots and difficulties in the public management field, and has the characteristics of appropriate difficulty and the availability of practical resources. The teachers and students discuss and agree on the knowledge reserve, thinking direction and learning path. The fourth is the project phased project task discussion and academic evaluation. It is mainly composed of the study group's results report and presentation, group discussion and teacher review summary. After each project task discussion, group and individual academic evaluations and feedback are provided to help students identify the direction of future efforts. The fifth is the writing and publication of student papers. Guide students to further phased project (task) to complete the sense of knowledge and experience over material resources to carry out anti-theoretical thinking and summary, writing essays and hair table paper process of obtaining.

Practice is a prerequisite for cultivating and developing the spirit of innovation and entrepreneurship. The research teaching reform of public administration courses should establish the subject of students' practice and entrepreneurial potential. The rich and varied practical teaching activities not only help to cultivate students' broad mind, comprehensive thinking and broad vision, but also help students to expand the application of knowledge and ability, and accumulate employment experience and capital. Public Administration teachers should uphold the openness philosophy, and actively with the government, institutions, non-governmental organizations, public enterprises and other public organizations exchange and interaction, building a number of teaching practice training base, from which constantly build Hefeng rich teaching practice resources. In the course teaching, students can be guided to the training unit to experience and research through the stage project (or task), or recommend the students to the training unit to internship, or invite practical experts to the school to share the exchange experience with the students. Research teaching has a strong openness, which is embodied in the openness of the subject boundary, the openness of the knowledge boundary, and the openness of the teaching place. The openness of teaching requires teachers to reform teaching methods, guide and support students to make self-conscious decision-making and creative experiments to stimulate and cultivate students' innovative entrepreneurial behavior. Specifically, public management professional teachers can use teaching methods, diary teaching methods, micro-teaching methods, and case analysis methods under the guidance of inspirational, participatory, exploratory, experiential, discoverative, and generative teaching concepts. Teaching methods such as group discussion and speech, social 
practice law.

In the way of students' academic evaluation, the traditional examination-type evaluation method is changed, and the combination of formative evaluation and summary evaluation is adopted. The evaluation data of formative evaluation mainly includes the public management theory (model) logic deduction problem, public management case analysis, public organization field research project, classroom attendance, classroom discussion participation performance, public management classic academic work reading and other multi-evaluation materials; evaluation subject Including statistical results, in order to prevent the phenomenon of "free rider" in the group, the "contribution degree" indicator is introduced. The number of the group is multiplied by the individual contribution rate. The evaluation results are used to give play to the motivational guidance function of the evaluation, and the feedback information is immediately fed back to the students to help the students to clear the direction and focus of the follow-up efforts.

\section{Conclusion}

Researching the characteristics and functions of teaching itself, it is an effective strategy and choice to carry out research teaching reform in the teaching of public administration. Taking the teaching of public service management course as an example, this paper mainly analyzes and expounds the value of research-based teaching reform of public administration major courses, the main content and direction of reform. The effect of the design and practice of research-based teaching reform in public administration courses requires a period of time to test, summarize and improve the teaching practice. Therefore, the performance evaluation of the reform and its theoretical summary are issues that need further research.

\section{Acknowledgements}

Project Source: Education and Teaching Research Project of Jilin Engineering Normal University

Project Name: Research on Classroom Teaching Reform of "Public Service Management" in the "Internet +" Era

\section{References}

[1] Zhang Hua. On the problem of knowledge in teaching [J]. Global Education Outlook, 2008 (11): 8-9.

[2] Cao Shengli. Innovation and entrepreneurship education calls for analog teaching and experiential courses [J]. Experimental Technology and Management, 2009, 26(8): 1-4.

[3] Song Yuping. Activate the public management professional classroom with the instructional teaching [J]. Chinese Higher Education, 2014(6): 35-36.

[4] Qian Guoying, Xu Liqing. Innovative Ability and College Teaching Strategy: Strategies and Examples of Undergraduate Research Teaching Methods [M]. Beijing: Higher Education and Education Press, 2010: 45.

[5] Liu Weizhong. Difficulties and implementation priorities in research teaching [J]. Chinese Higher Education, 2006 (24): 36 